\title{
Transpiration of Anatolian black pine and sessile oak forest stands in a sub-humid region of Turkey
}

\author{
Mehmet Said Ozcelik ${ }^{\bowtie}$, Kamil Sengonul²
}

Ozcelik M. S., Sengonul K., 2021. Transpiration of Anatolian black pine and sessile oak forest stands in a sub-humid region of Turkey. Ann. For. Res. 64(1): 111-128.

\begin{abstract}
Transpiration is a key component of the watershed water budget. Therefore, determining the transpiration of forest stands with different characteristics have been of interest for watershed hydrology and forest management practices in a wide range of environments. The objectives of this study were to compare transpiration of Anatolian black pine (Pinus nigra Arn. subsp. pallasiana (Lamb.) Holmboe) and sessile oak (Quercus petraea (Matt.) Liebl.) tree stands and to model transpiration based on the measured climatic factors. Stand transpirations were calculated from sap flow measurements made by the trunk heat balance method. We conducted an exploratory factor analysis (PCR) to detect affecting meteorological factors of stand transpiration, and we developed linear regression equations to predict transpiration of pine and oak stands. Mean daily and yearly canopy transpiration (Ec) were 1.05 $\mathrm{mm}$ day $^{-1}$ and $378.3 \mathrm{~mm}$ year-1 for the pine stand and $3.52 \mathrm{~mm}^{-1 a y}{ }^{-1}$ and 801.7 $\mathrm{mm}$ year $^{-1}$ for the oak stand. There was a highly positive correlation between daily stand transpiration and wind speed, global radiation, air vapour pressure deficit and air temperature, but a negative correlation with relative humidity for both stands. Soil water potential had little effect on stand transpiration. The model equations accounted for $81 \%$ of the variations in transpiration for the pine stand and $85 \%$ for the oak stand. Therefore, the transpiration of forest stands should be considered for effective vegetation management practices, as model equations to estimate the transpiration of pine and oak stands in the region.
\end{abstract}

Keywords: principal component regression, sap flow, trunk heat balance, watershed management, vegetation management.

Addresses: ${ }^{1}$ Department of Watershed Management, Faculty of Forestry, Isparta University of Applied Sciences, Isparta, Turkey| ${ }^{2}$ Department of Watershed Management, Faculty of Forestry, Istanbul University-Cerrahpasa, Istanbul, Turkey.

$\varpi$ Corresponding Author: Mehmet Said Ozcelik (mehmetozcelik@isparta. edu.tr; ozceliksmehmet@gmail.com).

Manuscript received September 27, 2020; revised June 10, 2021; accepted June $10,2021$. 


\section{Introduction}

Plant cover in watersheds plays an important role in hydrologic cycle by intercepting rainfall and transpiring water from the soil to the atmosphere (Edwards et al. 2015). For instance, Schlesinger and Jasecho (2014) found that about $39 \%$ of the precipitation returned to the atmosphere via transpiration. Globally, most of the transpiration takes place in forest ecosystems and, therefore, forest transpiration significantly affects the land energy balance, hydrological responses of watersheds and climate at the regional and global scales (Asbjornsen et al. 2011). The importance of freshwater supplies throughout Turkey is growing due to population increase and industrial development; therefore, accurate water budget measurements are critical to determining how the water is currently being used and how much water is available. Water consumption for different forest stands via transpiration becomes an essential issue in this frame due to its importance in the watershed water budget.

On the other hand, water use strategies and responses to the environmental factors across tree species vary according to their growth characteristics and transpiration regulation. Therefore, it is possible to see one species transpiring much more water than another species under the same site conditions (Wullschleger et al. 2001). Consequently, the growth characteristics of tree species should be taken into account when forestry activities are implemented in a watershed (Dierick \& Hölscher 2009).

The relationship between the individual tree transpiration as well as stand transpiration, and the climatic factors have been of interest in recent years (Granier et al. 1996, Oren \& Pataki 2001, Liu et al. 2009, Du et al. 2011, Jiao et al. 2016). Since direct transpiration studies need experimental background, specific devices and long monitoring periods in the field conditions, developing simple regression models based on meteorological parameters can be beneficial tools for predicting transpiration within the watershed water cycles. Multivariate analyses such as multiple linear regression, stepwise regression and principal component regression analyses have been used to determine the relationship between sap flow and climatic variables in previous studies (O'Brein et al. 2004, Deng et al. 2015, Pei et al. 2019) and some equation models are available based on the climatic factors for some regions to predict treeand stand-scale forest transpiration (O'Brein et al. 2004, Whitley et al. 2008, Bosch et al. 2014).

Sap flow method was used on different plant species with various aims worldwide under different climatic conditions, and it is the most common approach for transpiration measurements (Poyatos et al. 2016). Since sap flow through tree trunks countervails transpiration on a daily and seasonal basis, the method allows measuring whole tree crown transpiration (Köstner 2008). Sap flow method has some advantages compared to other methods. This method can be used to separate tree transpiration from evapotranspiration (Wilson et al. 2000), measures the water consumption of individual trees as well as forest stands in multiple time scales (Cermak et al. 2004) and perform well in heterogeneous topography (Martin et al. 2007). Moreover, long-term monitoring of forest transpiration and distinguishing intra and interannual variability is possible with the sap flow method (Granier et al. 1996).

On the other hand, there are still some uncertainties for the sap flow method, and there are intra and inter method variabilities to be considered when using sap flow methods (Flo et al. 2019). For instance, it is suggested to use species-specific calibration equations for some methods such as thermal dissipation (TD) and heat field deformation (HFD) methods to increase their accuracy (Fuchs et al. 2017). The sensor length also needs to be considered so that sensors are not placed in non-conductive tissue (Renninger \& Schafer 2012). The trunk heat balance (THB) method used in the present 
study, on the other hand, does not require specific calibration (Kucera \& Urban 2012).

Pine-oak ecosystems are distributed globally, and they dominate the forest ecosystems particularly in the Mediterranean, as pure stands and mixed stands (Sheffer 2012). Despite existing in the same ecosystems, they differ in leaf types, anatomy, hydraulic conductivity for water transport, and pines are evergreen, whereas oaks are mostly deciduous, suggesting that they have different strategies for using water (Renninger et al. 2015). Studies have been conducted to understand how these differences affect transpiration, water use efficiency, resource use and drought response among pine-oak ecosystems worldwide (Kolb \& Stone 2000, Poyatos et al. 2008, SanchezCosta et al. 2014, Aguade et al. 2015, Renninger et al. 2015). However, there is still a lack of information about the transpiration and water usage differences about pine and oak stands in Turkey, where it has a rich collection for both species.

Anatolian black pine (Pinus nigra Arn. subsp. pallasiana (Lamb.) Holmboe) is one of the most common and economically important natural conifer species growing in Turkey (Deligoz \& Carus 2006). Black pine grows on all kinds of parent materials within the EuroSiberian, Mediterranean and Irano-Turanian floristic regions of Turkey and establishes habitats ranging from semi-arid to sub-humid climatic zones. Its distribution ranges from the sea level in the Black sea coast to $2000 \mathrm{~m}$ high in the mountainous areas (Atalay \& Efe 2012) and covers $1,396,511$ ha as productive high forest and 807,870 ha as degraded high forest. It is also one of the most used species in afforestation works in Turkey (Karadag 1999).

Eighteen oak species naturally growing in Turkey make it the richest habitat of Quercus species in the western Palaearctic (Ugurlu et al. 2012). Oak forests cover approximately $26 \%$ of which corresponds to 5,886,195 ha forested areas in Turkey (GDF 2015). Oak species have a great diversity in North-Western Turkey, and sessile oak (Quercus petraea (Matt.) Liebl.) is one of the widespread among oak species (Uslu \& Bak1s 2012). According to climate types, sessile oak populations are primarily distributed in sub-humid regions of Turkey (Yucedag \& Gailing 2013).

Several studies were conducted about forestry practices and their effect on watershed hydrology in the last couple of decades in the Belgrad Forest (Serengil et al. 2007a, Serengil et al. 2007b, Gokbulak et al. 2016, Yurtseven et al. 2017, Yurtseven et al. 2018, Erdogan et al. 2018), the response of soil moisture and soil temperature to vegetation change from forest to herbaceous vegetation (Ozkan \& Gokbulak 2017), effects of forest canopy cover on water chemical quality (Eisalou et al. 2013) and calculation of evapotranspiration with catchment water balance equation (Ozhan et al. 2010). Ozhan (1982) reported that 28.3\% of the precipitation returns to the atmosphere via interception in pine stands and $15.6 \%$ in oak stands in the Belgrad Forest. Therefore, to decrease interception Cepel (1986) suggested that priority should be given to broad-leaved species in the watersheds which supply freshwater for domestic use. However, these researchers did not consider the transpiration of the compared species. Although these studies made an enormous contribution to understanding the effect of watershed management practises on watershed hydrology in the study site, transpiration measurements were not directly carried out at the tree and stand scale.

Therefore, the main goals of this study were to compare transpiration of pure Anatolian black pine and sessile oak stands growing in the same climatic and topographic conditions with direct measurements to evaluate their role in watershed management practices. Moreover, we aim to determine the correlation between stand transpiration and climatic factors for the study sites and present simple mathematical models for estimating canopy transpirations according to the measured meteorological variables representing the study site and 
similar sites in the region. The study results gave further information for the transpiration of forest stands in Turkey and provided the scientific base for decision-makers for better and effective vegetation management strategies in the watersheds.

\section{Material and Methods}

\section{Study site and stand characteristics}

The study site was Atatürk Arboretum within the borders of Belgrad Forest - Istanbul ( $41^{\circ} 09^{\prime}$ $\left.48^{\prime \prime}-41^{\circ} 10^{\prime} 55^{\prime \prime} \mathrm{N}, 28^{\circ} 57^{\prime} 27^{\prime \prime}-28^{\circ} 59^{\prime} 27^{\prime \prime} \mathrm{E}\right)$. Two forest stands next to each other $(<200 \mathrm{~m}$ linear distance) were selected as representative of resinous (Pinus nigra Arn. subsp. pallasiana (Lamb.) Holmboe) and broad-leaved (Quercus petraea (Matt.) Liebl.) tree species (Fig. 1). Both stands have similar site characteristics: aspect, elevation from sea level, soil, topography, and climate. In the site, mean annual precipitation is around $1180 \mathrm{~mm}$, and mean annual temperature is $12.8^{\circ} \mathrm{C}$. August is the warmest month with a mean temperature of $21.8^{\circ} \mathrm{C}$, and January is the coldest month with a mean temperature of $4.7^{\circ} \mathrm{C}$. The soils are usually shallow, medium to good permeability rates and clay loam in texture with high organic matter. The parent material is Neocene loamy, gravelly deposits (Serengil et al. 2007a). The elevation from the sea level is $90 \mathrm{~m}$.

The basal area and density were $54.8 \mathrm{~m}^{2}$ and about 975 trees per ha in the pine stand, while they were $57.78 \mathrm{~m}^{2}$ and about 1500 trees per ha in the oak stand, respectively. Mean tree

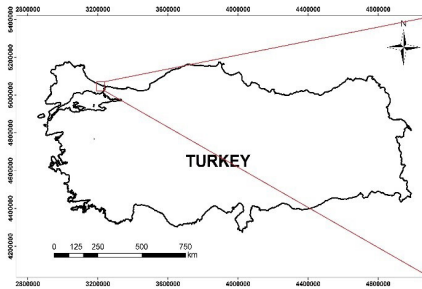

Figure 1 Location of the study site.

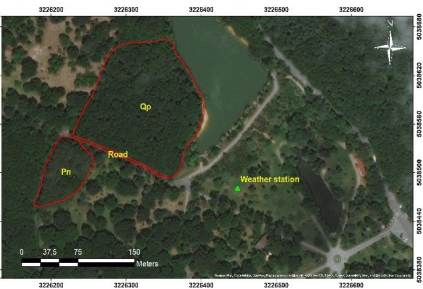

height was $14.5 \mathrm{~m}$, with a mean diameter of 25.2 $\mathrm{cm}$ at breast height in the pine plot, whereas it was $16.1 \mathrm{~m}$ with a mean diameter of $20.7 \mathrm{~cm}$ at breast height in the oak stand. The overall topography of the stands was flat. The pine plot had dense understory vegetation, mainly consisting of Erica arborea L. and Pteridium aquilinum (L.) Kuhn.

In contrast, there was no understory vegetation in the oak plot. The study period covered two consecutive calendar years between 1.1.2016 and 1.1.2018. Six sample trees representing each stand were selected based on the "quantiles of total" method briefly described in Cermak et al. (2004). The information about sampled trees was given in Table 1.
Table 1 Stand characteristics of the Pinus nigra and Quercus petraea experimental plots.

\begin{tabular}{lrrr}
\hline $\begin{array}{l}\text { Species/ } \\
\text { Tree ID }\end{array}$ & DBH (cm) & Height (m) & $\begin{array}{c}\text { Bark Thickness } \\
(\mathbf{c m})\end{array}$ \\
\hline Pinus nigra Arn. subsp. pallasiana & (Lamb.) Holmboe \\
P1 & 19.5 & 14.5 & 2.3 \\
P2 & 23 & 16.5 & 2.7 \\
P3 & 25.5 & 14 & 3.1 \\
P4 & 29 & 15.5 & 3.4 \\
P5 & 32 & 17 & 3.7 \\
P6 & 40 & 16.5 & 3.9 \\
Stand Mean & $25.2 \pm 6.9$ & $14.5 \pm 1.8$ & $/$ \\
\hline Quercus petraea (Matt.) Liebl & & \\
Q1 & 15.5 & 20 & 0.8 \\
Q2 & 21 & 17.5 & 1.2 \\
Q3 & 24 & 18 & 1.5 \\
Q4 & 28 & 19.5 & 1.5 \\
Q5 & 34 & 18.5 & 1.8 \\
Q6 & 35 & 18 & 1.8 \\
Stand Mean & $20.7 \pm 7.5$ & $16.1 \pm 3.3$ & $/$ \\
\hline
\end{tabular}




\section{Meteorological observations}

Data for wind speed $\left(\mathrm{U}, \mathrm{m} \mathrm{s}^{-1}\right)$, air temperature $\left(\mathrm{T}_{\text {air }},{ }^{\circ} \mathrm{C}\right)$, air relative humidity $(\mathrm{RH}, \%)$, precipitation $(\mathrm{mm})$ and global radiation $(\mathrm{RN}$, $\mathrm{W} \mathrm{m}^{-2}$ ) were collected automatically with two weather stations during the study period. The first one (combination of Minikin ERi and Minikin RTHi, EMS Brno, Brno, Czech Republic) was located at $2 \mathrm{~m}$ height in a bare open space close to the study area $(<200 \mathrm{~m}$ in the linear distance) (Fig. 1) and the second one (Campbell Scientific GRWS 1000, Logan, U.S.A) was located $5 \mathrm{~km}$ away from the study area. Data were recorded with 5 minutes intervals, and mean daily values were calculated as an average of all measurements. The air vapor pressure deficit (VPD) was estimated by combining the air temperature and relative humidity according to the following equation (Campbell \& Norman 1998):

$V P D=0.611 \times \exp \frac{17.502 T}{240.97+T}(1-R H)$

(Eq.1)

where VPD is air vapor pressure deficit $(\mathrm{kPa})$, $\mathrm{T}$ is air temperature $\left({ }^{\circ} \mathrm{C}\right)$, and $\mathrm{RH}$ is the air relative humidity (\%).

Soil water potential (SWP) ( $\Psi$, bar) was recorded at three soil depths $(10,25$ and 50 $\mathrm{cm}$ ) under the forest canopies with 60-minute intervals using three calibrated gypsum blocks (Delmhorst Inc, New Jersey, U.S.A) and Microlog SP3 data logger (EMS Brno, Brno, Czech Republic) for each stand. Mean daily SWP was calculated by averaging overall measurements from three sensors.

\section{Sap flow measurements}

Six sap flow sensors (EMS 81, EMS Brno, Brno, Czech Republic) functioning according to the trunk heat balance method were used for each stand to determine transpiration of the sampled trees (Cermak et al. 1973, Kucera et al. 1977). This method consisted of three heated electrodes, and one central nonheated (reference) electrode placed $10 \mathrm{~cm}$ below the upper electrodes. The amount of current electricity given to the system changes in relation to the sap flow rate to keep the temperature difference at $1 \mathrm{~K}$ between the reference and heated electrodes and needle type thermocouples with three measurement points of each were placed in the electrodes to record the temperature difference. An insertion tool supplied by the producer was used to place electrodes into the tree trunks, and it secures that the insulation on the electrodes covered the bark layer and phloem. Electrodes with different lengths were used for the pine $(8 \mathrm{~cm}$ long) and oak trees (6 cm long), ensuring that electrodes encompassed the entire sapwood of the oak trees and covering most of the sapwood depth in pine trees. Tree trunks were covered with a reflective shield after installing the sensors to isolate the created field of temperature around the sensors from the sun's convective heat loss and effects. The method calculates the heat balance of a defined heated space according to the equation below (Cermak et al. 2004):

$Q=\frac{P}{C w \times d \times \nabla T}-\frac{Z}{C w}$

where $Q$ is the sap flow rate $\left(\mathrm{kg} \mathrm{s}^{-1} \mathrm{~cm}^{-1}\right), P$ is the power of heat input (W), $\nabla^{\prime} \mathrm{T}$ is the temperature difference in the measuring points $(\mathrm{K}), c w$ is the specific heat of water $\left(\mathrm{J} \mathrm{kg}^{-1} \mathrm{~K}^{-1}\right)$, and $\mathrm{d}$ is the circumferential distance covered by the electrodes $(\mathrm{cm}) . \mathrm{Z} / \mathrm{Cw}$ symbolizes the heat loss determined under conditions where there is no sap flow (i.e. 03:00 a.m.), and therefore any heat loss from the system is addressed to the conduction through the wood tissue. Since the THB method yields sap flow of as kilograms, the Q of the measured area was multiplied with the length of the circumference of the xylem at the height of the installation to calculate total tree water use (Cermak et al. 2004).

\section{Scaling up sap flow to stand transpiration}

Stand transpiration $\left(\mathrm{E}_{\mathrm{c}}\right)$ can be summarized as the total water uptake by all trees divided 
by the stand area. To calculate stand-level transpiration, we selected the diameter at breast height $(\mathrm{DBH})$ as the biometric parameter of the sampled trees and the entire stand. Stand transpiration was calculated by considering the diameter classes as in common in forest inventories. Firstly, the sap flow of six sampled trees for both stands were used based on the DBH of the sampled trees and the diameter distribution of the trees in their stands separately, according to the methodology described in Cermak et al. (2004). Secondly, a linear regression was developed between $\mathrm{DBH}$ and $\mathrm{E}_{\mathrm{t}}$ (tree transpiration, $\mathrm{kg}$ tree ${ }^{-1}$ ) from the trees under study (Fig. 3a and 3b). Then, the daily water consumption of all trees $\left(\mathrm{E}_{\mathrm{c}}\right)$ in the study area was calculated using the distribution of trees per hectare according to $\mathrm{DBH}$ and the obtained regression equations. Finally, Ec was related to total stand area $\left(\mathrm{mm}\right.$ day $\left.^{-1}\right)$. EMS Mini32 (version 10.2.10.0, EMS Brno, Brno, Czech Republic) was used to convert the data logger values into sap flow $\left(\mathrm{kg} \mathrm{h}^{-1}\right)$, and Microsoft EXCEL software was used as an addition for the calculations of the scaling-up process of the sap flow data to the stand transpiration.

\section{Statistical analyses}

The Pearsons's correlation coefficients were applied between the hourly mean of stand transpiration and meteorological factors (i.e. U, Tair, RH, RN, VPD) with soil water potential (SWP). An independent sample t-test was conducted to examine whether there was a statistically significant difference between the means of annual water consumptions of the two forest stands. Correlation analyses and t-test were performed using Statistical Package for the Social Sciences 21.0 (SPSS IBM Corp.; Armonk, NY, USA).

Principle component regression analyses (PCR) were performed by following the steps described in Mevik \& Wehrens (2007) in the ("pls") package of R (R Core Team
2020, Vienna Australia, version 3.6.3) to model the relationship between the daily sum of transpiration and the daily mean meteorological factors beside soil water potential. PCR in the ("pls") package is the combination of two statistical methods: principal component analysis (PCA) and the multiple linear regression analysis (Mevik \& Wehrens 2007). In the present study, PCA was conducted to remove the collinearity between the explanatory variables since all the environmental factors strongly related. Using PCA, a series of related parameters (e.g. RH and VPD) reduced to a series of unrelated parameters. Root mean squared error of prediction (RMSEP) and the coefficient of determination $\left(\mathrm{R}^{2}\right)$ were used to determine the number of principal components included in the multiple regression analyses. The PCA analyses and multiple linear regression model predictions were obtained with ten-fold crossvalidation. The factor scores that come out of the PCA used in the multiple linear regression analysis and the measured water consumption of pine stand (EcPn) and oak stand (EcQp) were separately chosen as the response variables; whereas U, RN, Tair, RH, VPD and SWP were selected as the explanatory variables in the multiple linear regression analyses. The models were defined as follows in this study:

$$
E_{c}=\beta_{0}+\beta_{1} X_{1}+\beta_{2} X_{2}+\ldots . .+\beta_{n} X_{n}
$$

$E c$ is the response variable (stand transpiration), $X_{1}, X_{2} \ldots X_{n}$ are explanatory variables $(\mathrm{U}, \mathrm{RN}$, Tair, RH, VPD and SWP), $\beta_{0}$ is the constantcoefficient and $\beta_{1}, \beta_{2}$ are vectors of predictor variables derived by the multiple linear regression analyses.

The two calendar years data set was cleared to two vegetation periods (May 1 to November 1) for correlation and PCR analyses. The purpose of this clearance was to ensure that the foliation in the oak stand was completed. The November data was not included in the analysis because of the leaf senescence of oak trees in the first week of November. 


\section{Results}

\section{Environmental variables}

The daily mean air temperature was $13.4^{\circ} \mathrm{C}$, and the maximum air temperature was reached $36.6^{\circ} \mathrm{C}$ in September 2017. Global radiation showed similarity for both study years, and the mean global daytime radiation was $351 \mathrm{~W}^{-2}$ during the study period. Mean daily relative humidity was $79.1 \%$, and wind speed was $0.5 \mathrm{~m} \mathrm{~s}^{-1}$. Annual precipitation was $1085.4 \mathrm{~mm}$ in 2016 and $1049.3 \mathrm{~mm}$ in 2017, slightly lower than the long term average of $1184 \mathrm{~mm}$. The rainfall with the highest intensity was recorded in September 2017 with 52 $\mathrm{mm}$ precipitation within 6 hours. The mean daily air vapour pressure deficit was $0.3 \mathrm{kPa}$, and it reached 4.9 $\mathrm{kPa}$ maximum at 16:00 on the same day when the maximum air temperature was observed. Mean water potentials were -3.7 bar in 2016 and -3.2 bar in 2017 for the pine plot, and they were -2.5 bar in 2016 and -2.1 bar oak stand. in 2017 for the oak plot (Table 2).

The meteorological data recorded during the study period were within the data collected from a weather station near the study site for 37 years monitoring

Table 2 Mean values (mean \pm standard deviation) of some climate variables measured in the study site.

\begin{tabular}{lrrr}
\hline Variable & \multicolumn{2}{c}{ During the study period } & Long term \\
\cline { 2 - 3 } & Mean $\pm \mathbf{S D}^{*}$ & \multicolumn{1}{c}{ Range } & 12.8 \\
\hline Air temperature $\left({ }^{\circ} \mathrm{C}\right)$ & $13.4 \pm 8.2$ & $-11.6-36.6$ & $/$ \\
Global Radiation $\left(\mathrm{W} \mathrm{m}^{-2}\right)^{* *}$ & $351 \pm 209$ & $3.3-1008$ & 78.8 \\
Relative Humidity $(\%)$ & $79.1 \pm 17.6$ & $18.6-100$ & 1.8 \\
Wind Speed $\left(\mathrm{m} \mathrm{s}^{-1}\right)$ & $0.5 \pm 0.4$ & $0-5.7$ & 3.0 \\
Daily precipitation (mm)*** & $2.9 \pm 7.7$ & $0-62.7$ & $/$ \\
Soil water potential (bar) $(\mathrm{Pn})$ & $-3.6 \pm 4.3$ & $-0.15--14.5$ & $/$ \\
Soil water potential (bar) $(\mathrm{Qp})$ & $-2.1 \pm 3.9$ & $-0.15--14.3$ & \\
\hline
\end{tabular}

*Standard deviation. ** Global radiation in the column represents the mean daytime radiation. $* * *$ Daily precipitation data were obtained by dividing annual precipitation by 365. /: No data were obtained for this period. Pn: black pine stand, Qp: sessile

period from 1970 to 2006. The meteorological parameters followed a similar trend in both study years but showed significant variations within the years (Fig. 2).
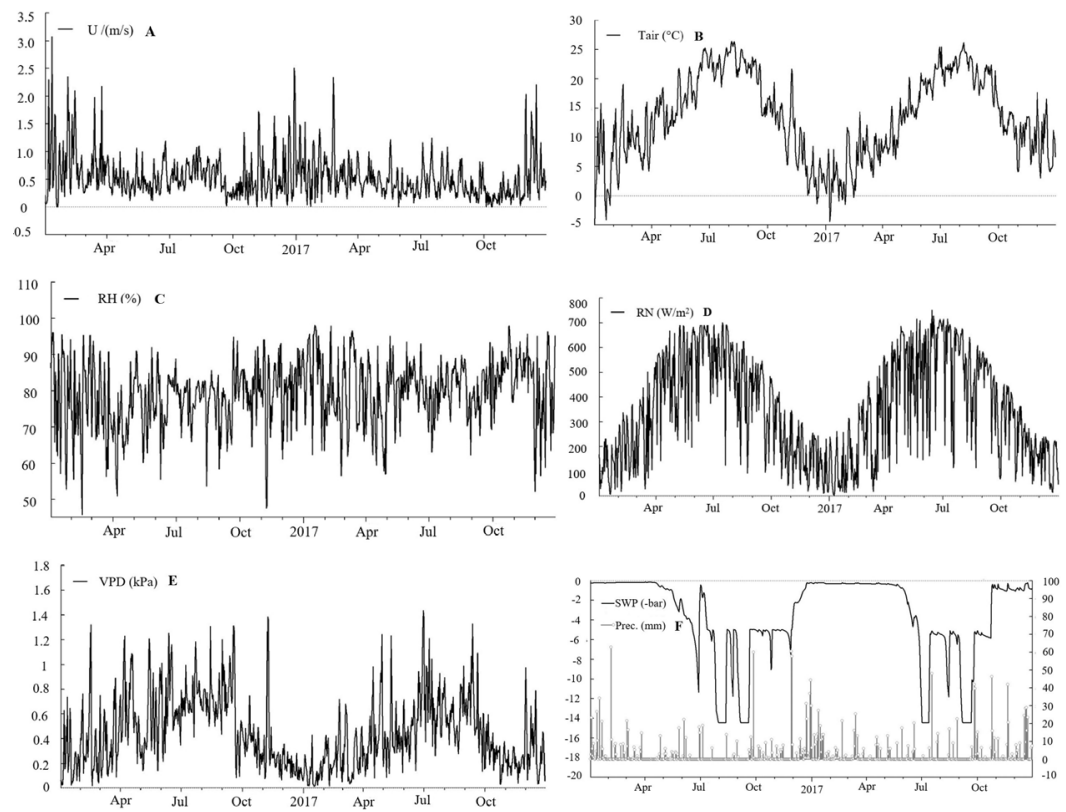

Figure 2 Temporal pattern in meteorological parameters during the study period in the study site. A: U (m/s), B: Tair $\left({ }^{\circ} \mathrm{C}\right), \mathrm{C}: \mathrm{RH}(\%), \mathrm{D}: \mathrm{RN}\left(\mathrm{W} / \mathrm{m}^{2}\right), \mathrm{E}: \mathrm{VPD}(\mathrm{kPa})$, F: SWP (bar) and precipitation (mm). 


\section{Sap flow and canopy transpiration of black pine stand}

The diurnal pattern of the measured sap flow in the six sampled pine trees was similar, but there were significant differences in the maximum values due to the size of the trees. Results showed that there was a strong correlation between the tree diameter and sap flow rate for pine stand $(r=0.95, p<0.05)$ (Fig. 3a). The minimum sap flow rates were observed for the P1, and the maximum sap flow rates were

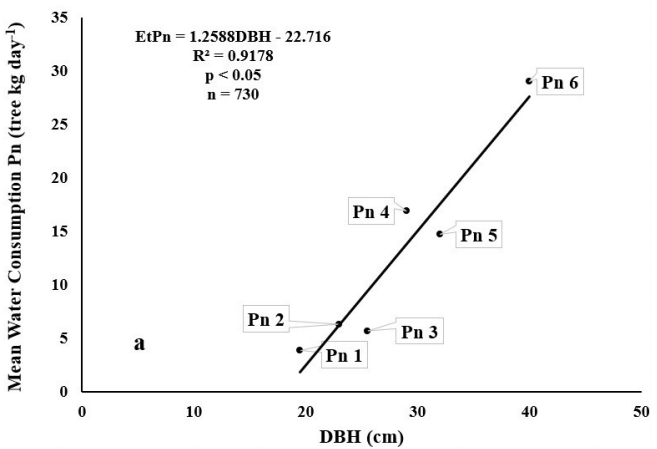

observed for the P6 (Fig. 4). The mean daily sap flow of the sampled trees varied between $3.7 \mathrm{~kg}$ and $28.7 \mathrm{~kg}$, while the daily maximum was reached up to $76.3 \mathrm{~kg}$ during the study period. The mean daily canopy transpiration of the stand was $1.05 \mathrm{~mm}$ and varied between 0.04 $\mathrm{mm}$ and $3.22 \mathrm{~mm}$ (Table 3). Half of the annual transpiration $(50 \%)$ occurred in the summer season, whereas only $4.5 \%$ took place in the winter season. Mean annual stand transpiration was $378.3 \mathrm{~mm}$ and changed between $396 \mathrm{~mm}$ in 2016 and $360 \mathrm{~mm}$ in 2017 (Fig. 5).

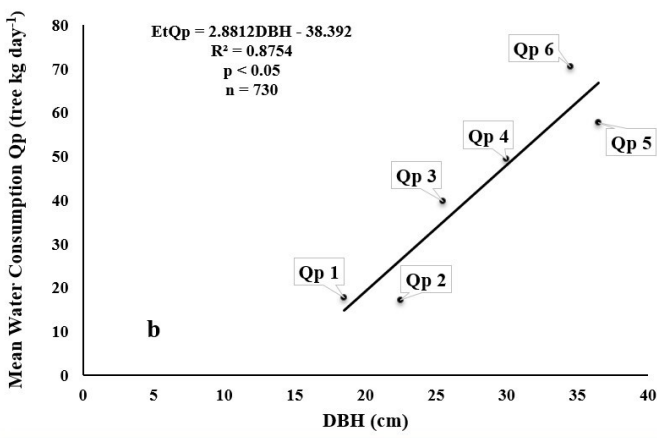

Figure 3 Relationship between DBH and mean daily transpiration of sample trees ( $\mathrm{kg}$ tree day ${ }^{-1}$ ) in black pine (a) and sessile oak (b) stands (Et: tree transpiration, Pn: black pine, Qp: sessile oak).

Table 3 The canopy transpiration of the experimental plots

\begin{tabular}{|c|c|c|c|c|c|c|c|}
\hline $\begin{array}{l}\text { Transpiration } \\
(\mathrm{Ec}) \text { of the } \\
\text { experimental } \\
\text { stands }(\mathrm{mm})\end{array}$ & $\begin{array}{l}\text { Mean daily } \\
\text { Ec }\end{array}$ & $\begin{array}{l}\text { The range } \\
\text { for daily Ec }\end{array}$ & Annaul Ec & $\begin{array}{l}\text { Ec in } \\
\text { Winter }\end{array}$ & $\begin{array}{l}\text { Ec in } \\
\text { Spring }\end{array}$ & $\begin{array}{c}\text { Ec in } \\
\text { Summer }\end{array}$ & $\begin{array}{c}\text { Ec in } \\
\text { Autumn }\end{array}$ \\
\hline Pn & $1.05 \pm 0.8^{\mathrm{a} *}$ & $0.04-3.22$ & $378.3 \pm 29.1^{*}$ & $17.26 \pm 0.3^{*}$ & $90.0 \pm 16.8^{*}$ & $188.8 \pm 14.7^{*}$ & $82.3 \pm 2.1 *$ \\
\hline Qp & $3.52 \pm 2.1^{\mathrm{b} *}$ & $0.02-8.4$ & $801.7 \pm 150.7^{*}$ & 1 & $147.2 \pm 44.2^{*}$ & $478.3 \pm 95.4^{*}$ & $176.2 \pm 10.2 *$ \\
\hline
\end{tabular}

* Standard deviation; means with different superscript letters are significantly different $(\mathrm{P}<0.001, \mathrm{n}=730)$; Pn: black pine, Qp: sessile oak.

\section{Sap flow and canopy transpiration of sessile oak stand}

Similarly to the pine stand, there was a strong correlation between diameter and sap flow in the oak stand $(\mathrm{r}=0.93 ; \mathrm{p}<0.05)$ (Fig. $3 b)$. Therefore, the minimum sap flow was observed in Q1 with a daily mean of $17.7 \mathrm{~kg}$ and the maximum was observed on Q6 with a daily mean of $70.4 \mathrm{~kg}$ (Fig. 4.). Recorded maximum daily sap flow was $162.4 \mathrm{~kg}$. Mean daily, and annual canopy transpirations from the oak stand were $3.52 \mathrm{~mm}$, and $801.7 \mathrm{~mm}$, respectively, and daily stand transpiration showed changes between 0.02 and $8.4 \mathrm{~mm}$ (Fig. 5). More than half of the annual canopy transpiration for oak stand occurred in the Summer months, $19 \%$ in Spring, while 21\% in Autumn (Table 3). The canopy transpiration sharply decreased with defoliation in the first week of November. 
Independent sample t-test results showed that there was a statistically significant difference in the scores of the black pine $($ Mean $=1.05$, Standard
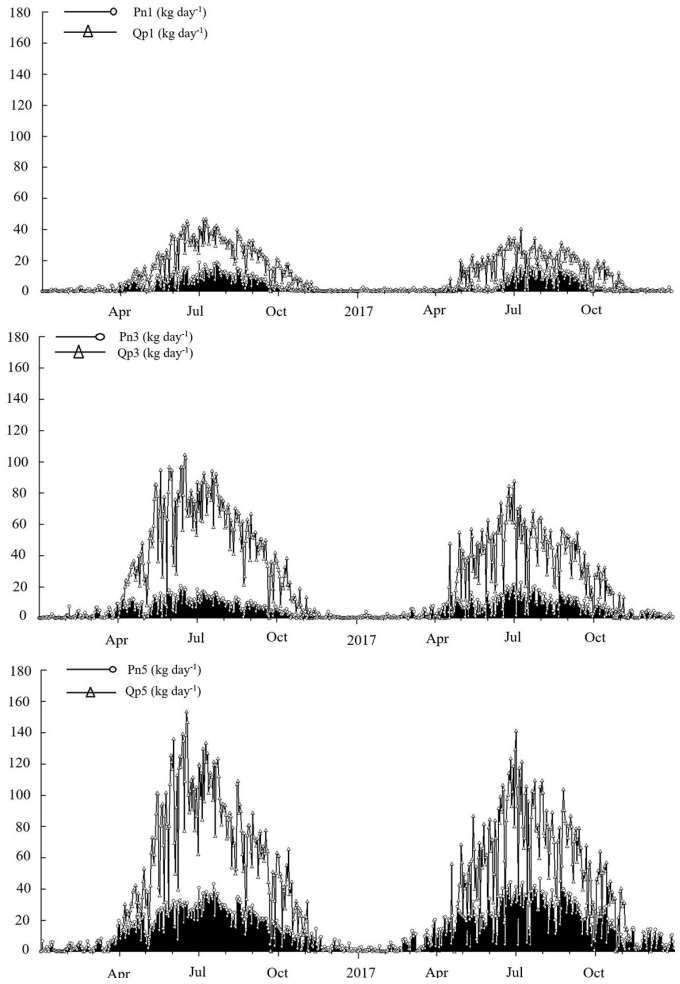

Figure 4 Daily water consumptions of sampled pine and oak trees according to the stand diameter classes. (Pn: pine, Qp: oak).

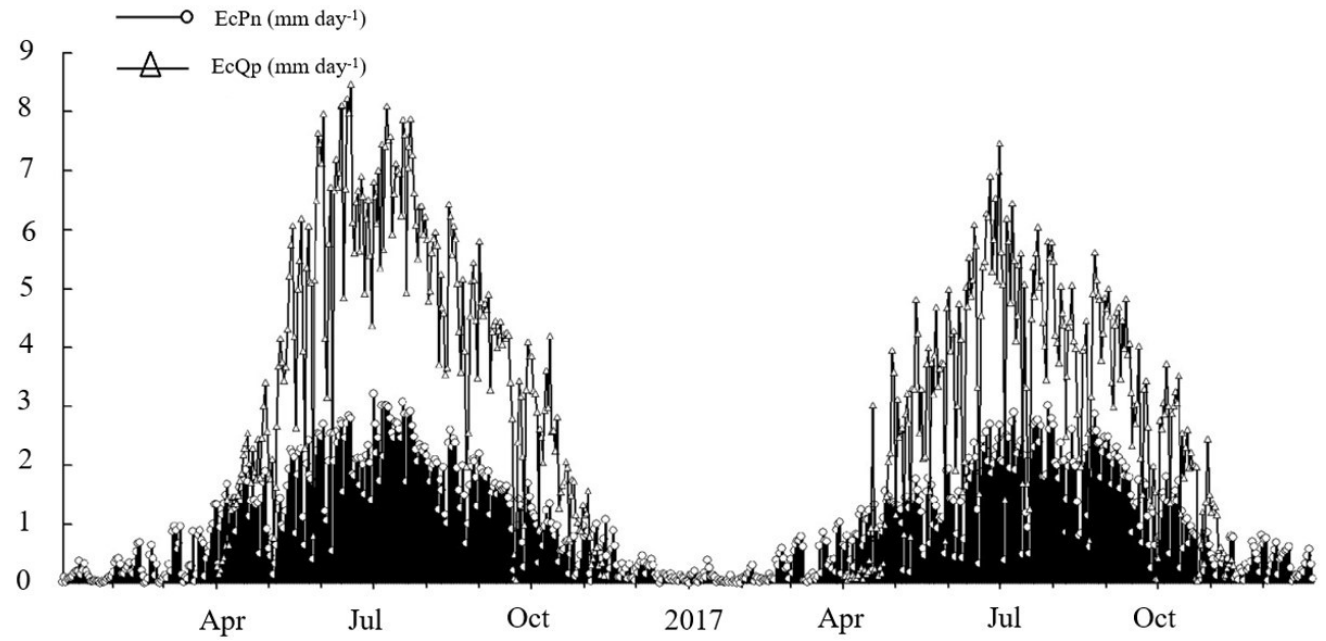

Figure 5 Canopy water consumptions $(\mathrm{Ec})$ of pine and oak stands during the study period. (Pn: pine stand, Qp: oak stand). 


\section{Correlation between canopy transpiration and meteorological factors}

The Pearson's correlation coefficients between hourly canopy transpiration and the climatic factors are presented in Table 4. Stand canopy transpiration positively correlates with $\mathrm{U}$, Tair,
$\mathrm{RN}$ and VPD but negative correlation with $\mathrm{RH}$ for both stands. According to the correlation analyses, soil water potential had little effect on stand transpirations. However, these effects were statistically significant. It can be further seen that canopy transpirations had the highest correlation coefficients with global radiation, air vapour pressure deficit and air temperature in both stands.

Table 4 Correlation coefficients between canopy transpiration and meteorological factors in black pine and sessile oak stands.

\begin{tabular}{|c|c|c|c|c|c|c|}
\hline $\mathbf{a}$ & EcPn & $\mathbf{U}$ & Tair & RH & $\mathbf{R N}$ & VPD \\
\hline$\overline{\mathrm{EcPn}}$ & 1 & & & & & \\
\hline $\mathrm{U}$ & $0.65 * *$ & 1 & & & & \\
\hline Tair & $0.69 * *$ & $0.64 * *$ & 1 & & & \\
\hline RH & $-0.79 * *$ & $-0.74 * *$ & $-0.67 * *$ & 1 & & \\
\hline $\mathrm{RN}$ & $0.83 * *$ & $0.69 * *$ & $0.61 * *$ & $-0.68 * *$ & 1 & \\
\hline VPD & $0.82 * *$ & $0.77 * *$ & $0.81 * *$ & $-0.97 * *$ & $0.71 * *$ & 1 \\
\hline SWP & $-0.06^{* *}$ & $-0.04 * *$ & $-0.35 * *$ & $0.09 * *$ & 0.01 & $-0.17 * *$ \\
\hline b & EcQp & $\mathbf{U}$ & Tair & RH & RN & VPD SWP \\
\hline EcQp & 1 & & & & & \\
\hline $\mathrm{U}$ & $0.68 * *$ & 1 & & & & \\
\hline Tair & $0.69 * *$ & $0.57 * *$ & 1 & & & \\
\hline RH & $-0.81 * *$ & $-0.66^{* *}$ & $-0.64 * *$ & 1 & & \\
\hline $\mathrm{RN}$ & $0.92 * *$ & $0.67 * *$ & $0.60 * *$ & $-0.74 * *$ & 1 & \\
\hline VPD & $0.84 * *$ & $0.62 * *$ & $0.75 * *$ & $-0.93 * *$ & $0.76 * *$ & 1 \\
\hline SWP & $-0.05^{* *}$ & $-0.07 * *$ & $-0.34 * *$ & $0.08 * *$ & -0.00 & $-0.17 * *$ \\
\hline
\end{tabular}

a: pine stand data, $\mathrm{b}$ : oak stand data $(* *$ Significant at $\mathrm{P}<0.01)$.

\section{Modelling stand transpiration with PCR analyses}

Principal component regression analysis with ten-fold cross-validation was applied to the daily sum of stand canopy transpiration and mean daily climatic factors for both stands. The first and second principal components explained $95.7 \%$ and $4.2 \%$ variations of the data, respectively, for both data sets. Ec, RN and VPD were loaded most strongly to the principal components (Fig

6).
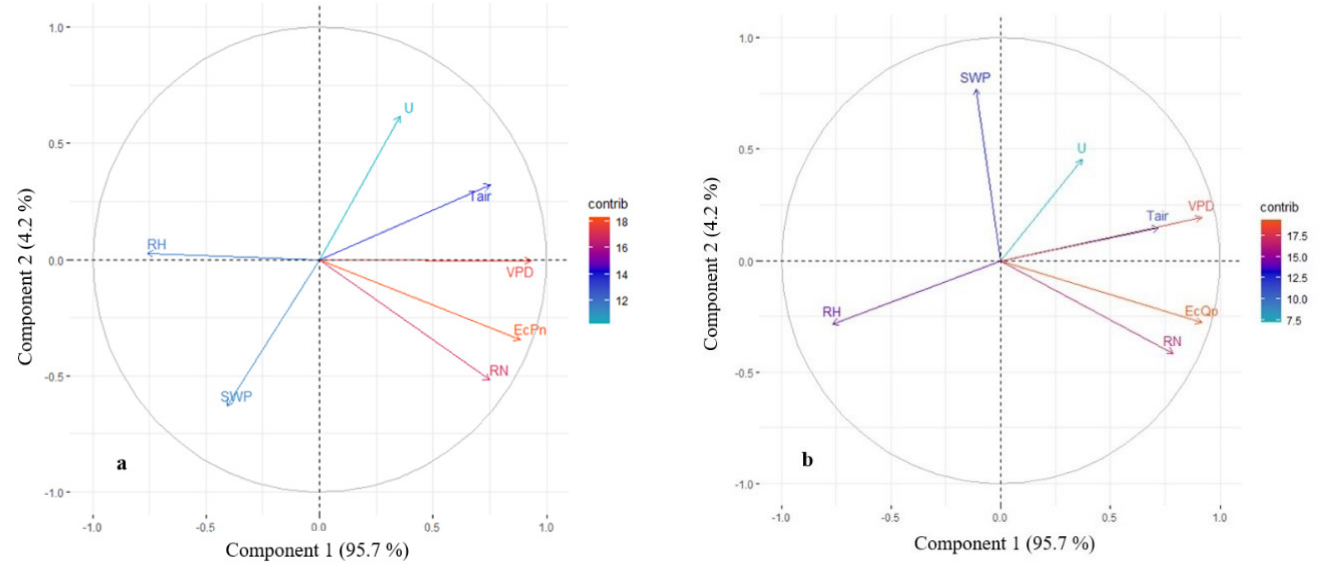

Figure 6 Contribution of the factors to the principal components. a: pine stand; b: oak stand. 
The number of principal components (PC) to be used in the model predictions was determined according to the root mean squared error of prediction (RMSEP) and the coefficient of determination $\left(\mathrm{R}^{2}\right)$. Since no significant contributions were determined after the second $\mathrm{PC}$ in the pine stand data and after the fifth PC in oak stand data, two PCs for pine stand and five PCs for oak stand were used further to fit linear models between canopy transpiration and meteorological factors (Fig. 7).
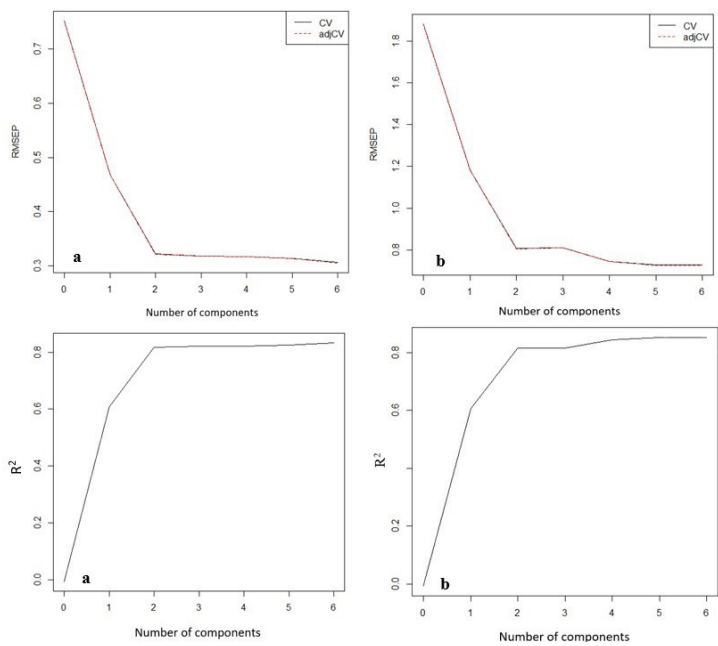

Figure 7 Root mean squared error of prediction (RMSEP) and coefficient of determination $\left(\mathrm{R}^{2}\right)$ values of the predicted principal components (a: pine stand data, b: oak stand data).

The following multiple-linear regression equations were obtained based on the factor scores that came out of the PCA analyses:

$$
\begin{gathered}
E c P n=-0.184-0.00000282 \times U+0.0000487 \times \text { Tair }+ \\
0.0000255 \times R H+0.0054 \times R N+0.00086 \times S W P+ \\
0.0011 \times V P D\left(R^{2}=0.81 ; n=368\right) \quad(\text { Eq. } 4) \\
E c Q p=1.679+0.00729 \times U+0.084 \times \text { Tair }-0.031 \times \\
R H+0.012 \times R N-0.0638 \times S W P+0.00158 \times \\
V P D\left(R^{2}=0.85 ; n=368\right) \quad(\text { Eq. } 5)
\end{gathered}
$$

where, $E c P n$ is the canopy transpiration of the pine stand (mm day $\left.{ }^{-1}\right), E c Q p$ is the canopy transpiration of the oak stand $\left(\mathrm{mm} \mathrm{day}{ }^{-1}\right)$,
$\mathrm{U}$ is the wind speed $\left(\mathrm{m} \mathrm{s}^{-1}\right)$, Tair is the air temperature $\left({ }^{\circ} \mathrm{C}\right), \mathrm{RH}$ is the relative humidity $(\%) \mathrm{RN}$ is the solar radiation $\left(\mathrm{W} \mathrm{m}^{-2}\right), \mathrm{SWP}$ is the soil water potential (bar) and VPD is the air vapour pressure deficit.

The relationships between measured and predicted values for linear equations are shown in (Fig. 8), which suggests that both equations could predict the stand transpiration successfully. In general, there is no systematic error in prediction, as revealed by the distribution of error around the 1:1 lines. The correlation coefficients (r) between measured and predicted canopy transpirations in pine and oak stands were 0.90 and 0.92 , respectively.

\section{Discussion}

\section{Comparison of black pine and sessile oak stand transpirations}

The first aim of this study was to compare transpirations of pine and oak stands in the same site conditions. The results are consistent with Wulschlegger et al. (1998), which summarizes the water use of 67 species belonging to 35 genera and indicates that the daily water consumption of trees via transpiration generally varies between $10 \mathrm{~kg}$ and 200 $\mathrm{kg}$. The daily mean transpiration of the individual Anatolian Black pine trees ranged from $4.17 \mathrm{~kg}$ to $28.95 \mathrm{~kg}$, and the daily maximum reached up to $76 \mathrm{~kg}$ in the present study. Compared to our results, less daily transpiration rates were reported for Scots pine (P. sylvestris L.) in Norway (13.1 kg) (Cermak et al. 1995); in Germany (25 kg) (Köstner et al. 1996), in Sweden (25 kg) (Cienciala et al. 2002) and a dry valley of Austria (25.4 $\mathrm{kg}$ ) (Wieser et al. 2014). In contrast, higher transpirations were found in other studies. For instance, Loustau et al. (1996) reported $275 \mathrm{~kg}$ daily water consumption via transpiration for maritime pine (P. pinaster Ait.) in Portugal. 

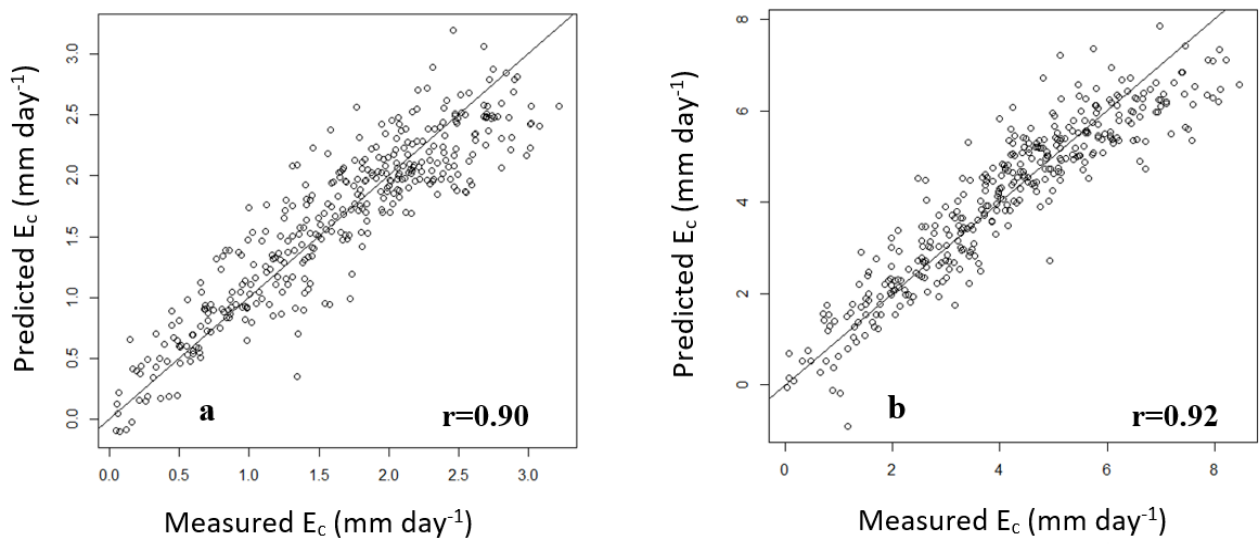

Figure 8 Relationship between measured and predicted values for canopy transpirations in pine (a) and oak (b) forest canopies.

As seen from these previously conducted studies, results vary from region to region because of differences in the tree species' climate conditions and development stages. These studies were conducted either in colder temperature or arid or semi-arid conditions. However, the daily transpiration of Anatolian Black pine showed more similarity with the results of the study carried out by Luis et al. (1995) in Mediterranean climate conditions. They found that daily transpiration for Canarian Island pine (P. canariensis C. Sm.) varied between $18.2 \mathrm{~kg}$ and $47.5 \mathrm{~kg}$. These values were lower than the values mainly reported from the Mediterranean ecosystem.

Canopy transpiration of pine stand ranged from 0.04 to $3.22 \mathrm{~mm}$ with a daily mean of $1.05 \mathrm{~mm}$, and it is within the range reported in the literature. Pallardy et al. (1995) reported 1-6 mm day ${ }^{-1}$ water consumption of evergreen coniferous forest stands in the vegetation period. Scots pine consumed $0.45 \mathrm{~mm}$ per day regarding the pine species, and this amount corresponded to $20 \%$ of the potential evapotranspiration in the study site (Cermak et al. 1995). In another study, $1.8 \mathrm{~mm}$ daily transpiration was found for Jack pine ( $P$. banksiana Lamb.) by Saugier et al. (1997) and $0.80 \mathrm{~mm}$ daily average and $253 \mathrm{~mm}$ total water consumption for Canarian Island pine by Luis et al. (1995).

Compared with values reported in the literature, the daily transpiration of Anatolian black pine stand appears among the results both obtained from coniferous species and pine species. Our results suggest that the water consumption of Anatolian black pine growing in a sub-humid climate of Istanbul is higher than Scots pine and lower than the maritime pine, according to results. On the other hand, these results could be representing the upper edge for the water consumption of Anatolian black pine because of the sub-humid climate and the higher precipitation in the study site.

Numerous reports can be found in the literature on the transpiration of different oak species. Renninger and Schafer (2012) observed $29.2 \mathrm{~kg}$ daily maximum transpiration on chestnut oak (Quercus prinus L.) and 41.6 $\mathrm{kg}$ on black oak (Q. velutina Lam.) growing in the same site. Wullschleger et al. (2001) state that white oak ( $Q$. alba L.) consumes a maximum of $76 \mathrm{~kg}$ of daily water while the red oak ( $Q$. rubra L.) growing in the same site has a maximum daily consumption of 46 kilograms via transpiration. Breda et al. (1993) reported an extreme value of $10 \mathrm{~kg}$ daily maximum water consumption for pedunculate oak (Q. robur L.) in aridity stress. On the 
other hand, Cermak et al. (1982) reported another extreme of $400 \mathrm{~kg}$ daily maximum water consumption in a floodplain forest for the same species. Nizinski and Saugier (1989) found $288.4 \mathrm{~mm}$ annual transpiration of a sessile oak (Q. petraea (Matt.) Liebl.) stand. The daily water consumption of sessile oak trees and the annual stand transpiration in the present study is consistent with the results of other studies. However, the transpiration rates of oaks showed a wide range based on the tree and stand structures, meteorological and topographic conditions.

Our results showed that oaks transpire more water than pines both at the tree and stand scale basis. In individual tree transpiration, oaks consumed 2 to 3 times more water than pines in the same diameter class. On a stand scale, the oak stand consumed 2.7 times more water than the pine stand, especially in the summer season when the water demand was maximum because of the lowest air humidity and the highest air temperatures (Fig. 4). Considering the ratio of transpiration of the stands to annual precipitation, it is seen that the Anatolian black pine stands returned approximately $36 \%$ of the annual precipitation, and the sessile oak stand $83 \%$ of the annual precipitation via transpiration in 2016. These values were calculated as $34 \%$ and $66 \%$, respectively, in 2017.

Compared to pine trees, higher water consumption of oak species can be attributed to different wood structure, root system, leaf type and shapes of these trees. Gymnosperms regarded as more advanced than the angiosperms in the evolutionary aspect; therefore, broad-leaved species has better growth rates in the areas with good growing conditions and high precipitation, such as in the study site (Becker et al. 1999). In addition, sessile oak is a ring-porous species and has a more advanced water transport system than pines (Granier et al. 1994). The second important factor is the difference in the leaves of trees. Renninger et al. (2015) found that oak leaves used ten percents more water and had higher transpiration rates per unit leaf area. McCulloh et al. (2010) indicated that ring-porous species (e.g. oaks) had the highest leaf-specific hydraulic conductivity while conifers (e.g. pines) had the lowest leafspecific conductivity among various tree types. Besides, embolism causes the loss of $50 \%$ of hydraulic conductivity in conifers because of the most significant "safety margin" between minimum in situ water potential and the actual water potential they had (Choat et al. 2012). Breda et al. (1993) indicated that sessile oak has a very effective root system, and they could pull water from deeper groundwater sources compared to pines (Renninger et al. 2015).

\section{The implication of tree and stand transpirations to watershed management practices}

Watershed management practices may include structural engineering practices, vegetation management practices, or both, depending on problems in the watershed (Ozhan 2004). Vegetation management practices are generally carried out to increase the water yield and quality of the water in the watershed (Bosch \& Hewlett 1982). Since it is impossible to change the topography and climatic conditions in a watershed by human actions to a large extent, water yield can be increased to some degree with vegetation management. It is suggested by Cepel (1986) to prefer broad-leaved species to coniferous species because of the lower interception rates (Ozhan 1982) for increasing water yield in a watershed. The water loss via transpiration in the oak stand was much higher than the pine stand in the present study. Hence the suggestion of preferring broadleaved species to the coniferous species to increase water yield in a watershed should be reconsidered by considering the transpiration of both stands, especially in Marmara Region.

Removal or thinning of the vegetation cover is another approach for increasing water yield 
in the streams. Bosch and Hewlett (1982) suggested that at least $20 \%$ of the vegetation cover should be removed to observe an increase in the streams for the watersheds similar to the study site. Serengil et al. (2007b) stated that $11 \%$ thinning of the forest cover increased at least $8 \mathrm{~mm}$ in the winter season water yield in Belgrad Forest in Istanbul. However, selecting the tree species according to their water use could improve the effectiveness of the thinning practices. For the study area, it can be interpreted that selecting oaks rather than pines for thinning practices could save more water from increasing water yield in the watersheds. In addition, the correlation between $\mathrm{DBH}$ and daily mean sap flow specifies that most of the transpiration in the stand was made by the trees with larger trunk diameters (Fig. 3a and 3b). Therefore it can be suggested that to increase water yield in the watersheds, trees with small diameter sizes should be maintained as long as soil erodilibility and topographical conditions permit.

\section{Correlation between stand transpiration and the meteorological factors and modelling stand transpiration with PCR}

Many studies evaluated relationships between the sap flow and the meteorological parameters of the study sites. However, results are not mainly consistent since many factors play an essential role in transpiration, and the main factors may vary. In our experiment, the Pearson's correlation analyses showed that Ec of both pine and oak stands had a significantly higher positive correlation with RN, VPD, Tair and $\mathrm{U}$, but a significantly negative correlation with RH in hourly timescale (Table 4). In other words, RN was the most effective factor, significantly increasing water consumption; while RH was the most effective variable, significantly decreasing water consumption in both stands. The correlation between SWP and stand transpiration was not strong, while it was statistically significant in both stands. These results are consistent with the results of the study by Guney et al. (2019) that photosynthetic active radiation and VPD were the most effective factors on the daily transpiration in Cedrus libani. Wieser et al. (2012) and Zimmermann et al. (2000) indicated that irradiance and air vapor pressure were the most effective factors influencing whole tree water consumption in $P$. cembra and $P$. sylvestris.

On the contrary, Granier et al. (1996) and Oren et al. (1999) stated that stand transpiration was closely dependent on air vapor pressure deficit and less correlated to the global radiation for several species in a natural rainforest and in a flooded Taxodium distichum forest. These differences can be explained as there was no soil water limitation in the studies, as mentioned earlier, and the meteorological conditions were far from the similarity with much higher temperature and precipitation rates than this study. Although it is known that global radiation, VPD and soil moisture content are the main drivers controlling transpiration (Meinzer et al. 2013), soil water potential had the most negligible impact on the canopy transpiration compared to other factors. This might be due to limited soil depth for SWP sensors measuring only the topsoil (50 cm maximum), and the trees would reach deeper horizons to take water.

Principal component regression analyses showed that the canopy transpiration of the pine and oak stands could effectively modelled based on the climatic factors in the study site (Fig. 8). The models performed well, explaining $81 \%$ and $85 \%$ (Eq. 4 and 5) of the variance in the pine and oak species, respectively. The responses of the stands to the meteorological factors were similar, although their differences in morphology, anatomy and adaptation to the study site indicate that climatic conditions may strongly influence the water loss of canopy irrespective of species characteristics (O’Brein et al. 2004). 


\section{Conclusion}

Tree transpiration $\left(\mathrm{E}_{\mathrm{t}}\right)$ and stand transpiration $\left(\mathrm{E}_{\mathrm{c}}\right)$ of the oaks $(Q$. petraea) were two times greater compared to those for pines (P. nigra) in sub-humid climate conditions in Istanbul. Solar radiation and air vapor pressure deficit were the strongest influencers and soil water potential was the weakest; however, this influence was statistically significant. Finally, to predict canopy transpiration of pine and oak stands based on the meteorological variables, we developed two simple models for watershed hydrology practices in the region. The results suggest that the water consumption of forest stands should be considered for water conservation aims in the watershed management practices. Decisions should be made regarding the total water loss via transpiration and interception together.

\section{Acknowledgements}

The study was financed by the Istanbul University Scientific Research Projects Unit with project number 52494. The authors are grateful to Mr Jiř́ Kučera from Environmental Measuring Systems (Brno, Czech Republic) and Prof. Jan Čermák from Mendel University (Brno, Czech Republic) for their help and contribution in the design of the study, obtaining the necessary sensors and field measurements. The authors thank Mr Sebahattin Serhat Turgut for his help in PCR analyses; they also thank Prof. Ferhat Gokbulak from Istanbul University for his helpful comments on the manuscript.

\section{References}

Aguade D., Poyatos R., Rosas, T., Martinez-Vilalta J., 2015. Comparative drought responses of Quercus ilex L. and Pinus sylvestris L. in a montane forest undergoing a vegetation shift. Forests 6(8): 2505-2529. https://doi.org/10.3390/f6082505

Asbjornsen H., Goldsmith G.R., Alvarado-Barientos M.S., Rebel K., Van Soch Floortje P., Rietkerk M., Chen J., Gotsch S., Tobon C., Geissert D.R., Gomez-Tagle
A., Vache K., Dawson T.E., 2011. Ecohydrological advances and applications in plant-water relations research: a review. Journal of Plant Ecology 4(1-2): 3-22. https://doi.org/10.1093/jpe/rtr005

Atalay I., Efe R., 2012. Ecological attributes and distribution of Anatolian Black Pine [Pinus nigra Arnold subsp. pallasiana Lamb. Holmboe] in Turkey. Journal of Environmental Biology 33(2): 509-519. PMID: 23424857

Becker P., Tyree M.T., Tsuda M., 1999. Hydraulic conductances of angiosperms versus conifers: similar transport sufficiency at the whole-plant level. Tree Physiology 19(7): 445-452. https://doi.org/10.1093/ treephys/19.7.445

Bosch J.M., Hewlett J.D. 1982. A review of catchment experiments to determine the effect of vegetation change on water yield and evapotranspiration. Journal of Hydrology 55(1/4): 3-23. https://doi. org/10.1016/0022-1694(82)90117-2

Bosch D.D., Marshal L.K., Teskey R., 2014. Forest transpiration from sap flux density measurements in a Southeastern Coastal Plain riparian buffer system. Agricultural and Forest Meteorology 187: 72-82. https://doi.org/10.1016/j.agrformet.2013.12.002

Breda N., Cochard H., Dreyer E., Grainer A., 1993. Field comparison of transpiration, stomatal conductance and vulnerability to cavitation of Quercus petraea and Quercus robur under water stress. Annals of Forest Science 50: 571-582. https://doi.org/10.1051/ forest: 19930606

Campbell G.S., Norman J.M., 1998. An introduction to environmental biophysics. 2nd ed., Springer-Verlag, New York, pp. 281.

Cermak J., Deml M., Penka M., 1973. A new method of sap flow rate determination in trees. Biologia Plantarum 15(3): 171-178. https://doi.org/10.1007/BF02922390

Cermak J., Ukehla J., Kucera J., Penka M., 1982. Sap flow rate and transpiration dynamics in the full-grown oak (Quercus robur L.) in the floodplain forest exposed to seasonal floods as related to potential evapotranspiration and tree dimensions. Biologia Plantarum 24 (6): 446460. https://doi.org/10.1007/BF02880444

Cermak J., Cienciala E., Kucera J., Lindroth A., Bednarova E., 1995. Individual variation of sap flow rate in large pine and spruce trees and stand transpiration: a pilot study at the central NOPEX site. Journal of Hydrology 168: 17-27. https://doi.org/10.1016/00221694(94)02657-W

Cermak J., Kucera J., Nadezhdina N., 2004. Sap flow measurements with some thermodynamic methods, flow integration within trees and scaling up from sampled trees to entire forest stands. Trees 18: 529-546. https://doi.org/10.1007/s00468-004-0339-6

Choat B., Jansen S., Brodribb T.J., Cochard H., Delzon S., Bhaskar R., et al. 2012. Global convergence in the vulnerability of forests to drought. Nature 491: 752 755. https://doi.org/10.1038/nature11688

Cienciala E., Mellander P.E., Kucera J., Oplustilova M., 
Ottoson-Löfvenius M., Bishop K., 2002. The effect of a north-facing forest edge on tree water use in a boreal Scots pine stand. Canadian Journal of Forest Research 32: 693-702. https://doi.org/10.1139/x02-013

Cepel N. 1986. Barajların yukarı yağış havzaları için arazi kullanım planlamasının ekolojik esasları. Istanbul Universitesi Orman Fakültesi Dergisi, Seri B, 36(2): 17-27. https://doi.org/10.17099/jffiu.79061

Deligoz A., Carus S., 2006. Statistical analysis of some seed and cone characteristics in the discriminant of seed stands of Anatolian Black Pine [Pinus nigra Arn. subsp. pallasiana (Lamb.) Holmboe]. Turkish Journal of Forestry 2(A): 13-22.

Deng J., Ding G., Gao G., Wu B., Zhang Y., Qin S., Fan W., 2015. The sap flow dynamics and response of Hedysarum scoparium to environmental factors in semiarid Northwestern China. PLoS One 10(7): e0131683. https://doi.org/10.1371/journal. pone. 0131683

Dierick D., Hölscher D., 2009. Species-specific tree water use characteristics in reforestation stands in the Philippines. Agricultural and Forest Meteorology 149(8): 1317-1326. https://doi.org/10.1016/j. agrformet.2009.03.003

Du S., Long-Wang Y., Kume T., Zhang J.G., Otsuki K., Yamanaka N., Liu G.B., 2011. Sap flow characteristics and climatic responses in three forest species in the semi-arid Loess Plateau region of China. Agricultural and Forest Meteorology 151: 1-10. https://doi. org/10.1016/j.agrformet.2010.08.011

Edwards P.J., Pillard K.W.J., Schoonover J.E., 2015. Fundamentals of forest hydrology. Journal of Contemporary Water Research and Education 154(1): 3-20. https://doi.org/10.1111/j.1936704X.2015.03185.x

Eisalou H.K., Sengonul K., Gokbulak F., Serengil Y., Uygur B., 2013. Effects of forest canopy cover and floor on chemical quality of water in broad leaved and coniferous forests of Istanbul, Turkey. Forest Ecology and Management 289: 373-377. https://doi. org/10.1016/j.foreco.2012.10.031

Erdogan B., Gokbulak F., Serengil Y., Yurtseven I., Ozcelik M.S., 2018. Changes in selected physical water quality characteristics after thinning in a forested watershed. Catena 166: 220-228. https://doi.org/10.1016/j. catena.2018.04.010

Flo V., Vilalta J.M., Steppe K., Schuldt B., Poyatos R., 2019. A synthesis of bias and uncertainty in sap flow methods. Agricultural and Forest Meteorology 271: 362374. https://doi.org/10.1016/j.agrformet.2019.03.012

Fuchs S., Leuschner C., Link R., Coners H., Schuldt B., 2017. Calibration and comparison of thermal dissipation, heat ratio and heat field deformation sap flow probes for diffuse-porous trees. Agricultural and Forest Meteorology 244-245: 151-161. https://doi. org/10.1016/j.agrformet.2017.04.003

GDF 2015. Türkiye'nin Orman Varlıg1. General Directorate of Forestry, Ankara, Turkey. Available
Online: https:/www.ogm.gov.tr/ekutuphane/Yayinlar/ T\%C3\%BCrkiye \%20Orman $\% 20$ Varl $\%$ C4\%B1\%C4\% 9F\%C4\%B1-2016-2017.pdf (accessed 4 July 2020).

Gokbulak F., Sengonul K., Serengil Y., Ozhan S., Yurtseven I., Uygur B., Ozcelik M.S., 2016. Effect of forest thinning on water yield in a sub-humid Mediterranean oak-beech mixed forested watershed. - Water Resources Management 30 (14): 5039-5049. https://doi.org/10.1007/s11269-016-1467-7

Grainer A., Anfodillo T., Sabatti M., Cochard H., Dreyer E., Tomasi M., Valentini R., Breda N., 1994. Axial and radial water flow in the trunks of oak trees: a quantitative and qualitative analyses. Tree Physiology 14: 1383:1396. https://doi.org/10.1093/ treephys/14.12.1383

Granier A., Huc R., Barigah S.T., 1996. Transpiration of natural rain forest and its dependence on climatic factors. Agricultural and Forest Meteolorology 78: 1929. https://doi.org/10.1016/0168-1923(95)02252-X

Guney A., Zimmermann R., Haas K., 2019. Sap flux and stem radius variations in mature Cedrus libani trees during the growing season. Turkish Journal of Agriculture and Forestry 43 (1): 36-47. https://doi. org/10.3906/tar-1802-115

Jiao L., Lu N., Sun G., Ward E.J., Fu B., 2016. Biophysical controls on canopy transpiration in a black locust (Robinia pseudoacacia) plantation on the semi-arid Loess Plateau, China. Ecohydrology 9: 1068-1081. https://doi.org/10.1002/eco.1711

Karadag M., 1999. Batı Karadeniz Bölgesinde karaçam (Pinus nigra Arnold ssp. pallasiana (Lamb.) Holmboe), doğal gençleştirme koşulları üzerine araştırmalar. Orman Bakanlığı Batı Akdeniz Araştırma Enstitüsü Müdürlüğü, Teknik Bülten No:4, Orman Bakanlığ Yayın No: 067, Müdürlük Yayın No:6, Bolu, Türkiye.

Kolb T., Stone J.E., 2000. Differences in leaf gas exchange and water relations among species and tree sizes in an Arizona pine-oak forest. Tree Physiology 20 (1) : 1-12. https://doi.org/10.1093/treephys/20.1.1

Köstner B., Biron P., Siegwolf R., Grainer A., 1996. Estimates of water vapor flux and canopy conductance of Scots pine at the tree level utilizing different xylem sap flow methods. Theoretical and Applied Climatology 53: 105-113. https://doi.org/10.1007/BF00866415

Köstner B., Matyssek R., Heilmeier H., Clausnitzer F., Nunn A.J., Wieser G., 2008. Sap flow measurement as a basis for assessing trace-gas exchange of trees. Flora 203: 14-33. https://doi.org/10.1016/j.flora.2007.09.001

Kucera J., Cermak J., Penka M., 1977. Improved thermal method of continual recording the transpiration flow rate dynamics. Biologia Plantarum 19: 413-420. https:// doi.org/10.1007/BF02922976

Kucera J., Urban J., 2012. History of the development of the trunk heat balance method in last forty years. Acta Horticulturae 951: 87-94.

Liu X., Kang S., Li F., 2009. Simulation of artificial neural network model for trunk sap flow of Pyrus pyrifolia and its comparison with multiple-linear regression. 
Agricultural and Forest Meteorology 96: 939-945. https://doi.org/10.1016/j.agwat.2009.01.003

Loustau D., Berbigier P., Roumagnae P., Arruda-Pacheco C., David J.S., Ferreira M.I., Pereira J.S., Tavares R., 1996. Transpiration of a 64-year-old maritime pine stand in Portugal. Oecologia 107: 33-42. https://doi. org/10.1007/BF00582232

Luis V.C., Jimenez M.S., Morales D., Kucera J., Wieser, G., 1995. Canopy transpiration of a Canary Islands pine forest. Agricultural and Forest Meteorology 135: 117123. https://doi.org/10.1016/j.agrformet.2005.11.009

Martin T. A., Brown K. J., Cermak J., Ceulemans R., Kucera J., Meinzer F. C., Rombold J.S., Sprugerl D.G., Hinckley T.M., 2007. Crown conductance and tree and stand transpiration in a second-growth Abies amabilis forest. Canadian Journal of Forest Research 27: 797808. https://doi.org/10.1139/x97-006

Meinzer F.C., Woodruff D.R., Eissenstat D., Lin H., Adams T., McCulloh K.A., 2013. Above- and belowground controls on water use by trees of different wood types in an eastern US deciduous forest. Tree Physiology 33: 345-356. Doi: 10.1093/treephys/tpt012

Mevik B.H., Wehrens R., 2007. The pls Package: principal component and partial least squares regression in $\mathrm{R}$. Journal of Statistical Software 18(2): 1-24. https://doi. org/10.18637/jss.v018.102

McCulloh K., Sperry J., Lachenbruch B., Meinzer F.C., Reich P.B., Voelker S., 2010. Moving water well: comparing hydraulic efficiency in twigs and trunks of coniferous, ring-porous, and diffuse- porous saplings from temperate and tropical forests. New Phytologist 186: 439-450. https://doi.org/10.1111/j.14698137.2010.03181.x

Nizinski J., Saugier B. 1989. A model of transpiration and soil-water balance for a mature oak forest. Agricultural and Forest Meteorology 47(1): 1-17. https://doi. org/10.1016/0168-1923(89)90082-8.

O’brein J.J., Oberbauer S.F., Clark D.B., 2004. Whole tree xylem sap flow responses to multiple environmental variables in a wet tropical forest. Plant Cell and Environment 27: 551-557. https://doi.org/10.1111/ j.1365-3040.2003.01160.x

Oren R., Sperry J.S., Katul G.G., Pataki D.E., Ewers B.E., Phillips N., Schäfer K.V.R., 1999. Survey and synthesis of intra- and interspecific variation in stomatal sensitivity to vapor pressure deficit. Plant Cell and Environment 22: 1515-1526. https://doi.org/10.1046/ j.1365-3040.1999.00513.x

Oren E., Pataki D.E., 2001. Transpiration in response to variation in microclimate and soil moisture in southeastern deciduous forests. Oecologia 127: 549559, https://doi.org/10.1007/s004420000622

Ozhan S., 1982. Belgrad Ormanındaki Bazı Meşcerelerde Evapotranspirasyonun Deneysel Olarak Saptanması ve Sonuçların Ampirik Modellerle Karşılaştırılması. Istanbul Üniversitesi Orman Fakültesi Yayınları, Yayın No: 311, Istanbul, pp. 181.

Ozhan S., 2004. Havza Amenajmanı. Istanbul Üniversitesi
Orman Fakültesi Yayınları I.U. Rektörlük Yayın No: 4510, Orman Fakültesi Yayın No: 481, Istanbul, pp. 384

Ozhan S., Gökbulak F., Serengil Y., Ozcan M., 2010. Evapotranspiration from a mixed deciduous forest ecosystem. Water Resources Management 24(10): 2353-2363. https://doi.org/10.1007/s11269-009-9555-6

Ozkan U., Gokbulak F., 2017. Effect of vegetation change from forest to herbaceous vegetation cover on soil moisture and temperature regimes and soil water chemistry. Catena 149: 158-166. https://doi. org/10.1016/j.catena.2016.09.017

Pallardy S.G., Cermak J., Ewers F.W., Kaufmann M.R., Parker W.C., Sperry J.S., 1995. Water Transport Dynamics in Trees and Stands. In: W.K. Smith and T.M. Hinckley. (ed.), Resource Physiology of Conifers: Acquisition, Allocation and Utilization, Academic Press: San Diego, pp 301-368.

Pei Z., Hao S., Pang G., Wang, K., Liu T., 2019. Sap flow of Salix psammophila and its principal influencing factors at different slope positions in the Mu Us desert. PLoS One 14(12): e0225653. https://doi.org/10.1371/ journal.pone. 0225653

Poyatos R., Llorens P., Pinol J., Rubio C., 2008. Response of Scots pine (Pinus sylvestris L.) and pubescent oak (Quercus pubescens Willd.) to soil and atmospheric water deficits under Mediterranean mountain climate. Annals of Forest Science 65: 306. https://doi. org/10.1051/forest:2008003

Poyatos R., Granda V., Molowny-Horas R., Mencuccini M., Steppe K., Martínez-Vilalta J,. 2016. SAPFLUXNET: Towards a global database of sap flow measurements. Tree Physiology 36: 1449-1455. https:// doi.org/10.1093/treephys/tpw110

Renninger H.J., Schafer K.V.R., 2012. Comparison of tissue heat balance and thermal dissipation derived sap flow measurements in ring porous oak and a pine. Frontiers in Plant Science 3: 103. https://doi. org/10.3389/fpls.2012.00103

Renninger H.J., Carlo N.J., Clark K.L., Schafer K.V.R., 2015. Resource use and efficiency, and stomatal responses to environmental drivers of oak and pine species in an Atlantic Coastal Plain forest. Frontiers in Plant Science 6: 297. https://doi.org/10.3389/ fpls.2015.00297

Sanchez-Costa E., Poyatos, R., Sabate S., 2015. Contrasting growth and water use strategies in four co-occurring Mediterranean tree species revealed by concurrent measurements of sap flow and stem diameter variations. Agricultural and Forest Meteorology 207: 24-37. https://doi.org/10.1016/j.agrformet.2015.03.012

Saugier B., Granier A., Pontailler J.Y., Dufrene E., Baldocchi D., 1997. Transpiration of a boreal pine forest measured by branch bag, sap flow and micrometeorological methods. Tree Physiology. 17: 511-519. https://doi.org/10.1093/treephys/17.8-9.511

Serengil Y., Gokbulak F., Ozhan S., Hizal A., Sengonol K., 2007a. Alteration of stream nutrient discharge with increased sedimentation due to thinning of a 
deciduous forest in Istanbul. - Forest Ecology and Management 246, 264-272. https://doi.org/10.1016/j. foreco.2007.04.008

Serengil Y., Gokbulak F., Ozhan S., Hizal A., Sengonul K., Balcı A.N., Ozyuvac1 N., 2007b. Hydrological impacts of a slight thinning treatment in a deciduous forest ecosystem in Turkey. Journal of Hydrology 333(2-4): 569-577. https://doi.org/10.1016/j.jhydrol.2006.10.017

Schlesinger W.H., Jasecho S., 2014. Transpiration in the global water cycle. Agricultural and Forest Meteorology 189-190: 115-117. https://doi.org/10.1016/j. agrformet.2014.01.011

Sheffer E., 2012. A review of the development of Mediterranean pine-oak ecosystems after land abandonment and afforestation: Are they novel ecosystems? Annals of the Forest Science 69: 429-443.

Ugurlu E., Rolecek, J., Bergmeier E., 2012. Oak woodland vegetation of Turkey - a first overview based on multivariate statistics. Applied Vegetation Science 15 (4): 590-608. https://doi.org/10.1111/j.1654109X.2012.01192.x

Uslu E., Bak1s Y., 2012. Geographic distribution of Turkish Oaks. Dendrobiology 67: 41-48.

Wang., Gao J.G., Zhao P., Zhu L.W., Ouyang L., Ni G.Y., Zhao X.H., 2018. Biotic and abiotic-driven variations of the night-time sap flux of three co-occurring tree species in a low subtropical secondary broadleaf forest. AoB Plants 10(3): ply025. https://doi.org/10.1093/ aobpla/ply025

Whitley R., Zeppel M., Armstrong N., Macinnis-Ng C., Yunusa I., Eamus D., 2008. A modified Jarvis-Stewart model for predicting stand-scale transpiration of an Australian native forest. Plant and Soil 305: 35-47. https://doi.org/10.1007/s11104-007-9399-x

Wieser G., Leo M., 2012. Whole-tree water use by Pinus cembra at the treeline in the Central Tyrolean Alps. Plant Ecology and Diversity 5(1): 81-88. https://doi.org $/ 10.1080 / 17550874.2012 .688070$

Wieser G., Leo M., Oberhuber W., 2014. Transpiration and canopy conductance in an inner alpine Scots pine (Pinus sylvestris L.) forest. Flora 209: 49-49. https:// doi.org/10.1016/j.flora.2014.06.012
Wilson K.B., Hanson P.J., Baldocchi D.D., 2000. Factors controlling evaporation and energy partitioning beneath a deciduous forest over an annual cycle. Agricultural and Forest Meteorology 102(2-3): 83-103. https://doi. org/10.1016/S0168-1923(00)00124-6

Wullschleger S.D., Meinzer F.C., Vertessy R.A., 1998. A review of whole plant water use studies in trees. Tree Physiology 18: 499-512. https://doi.org/10.1093/ treephys/18.8-9.499

Wullschleger S.D., Hanson P., Todd D.E., 2001. Transpiration from multi-species deciduous forest as estimated by xylem sap flow technique. Forest Ecology and Management 143: 205-213. https://doi. org/10.1016/S0378-1127(00)00518-1

Yurtseven I., Gokbulak F., Serengil Y., Erdogan B., Ozcelik M.S., Sengonul K., Ozhan S., 2017. Response of selected water chemical quality parameters to slight thinning in a mature oak-beech forest ecosystem under sub-humid climate conditions. European Journal of Forest Research 136(4): 653-664. https://doi. org/10.1007/s10342-017-1062-3

Yurtseven I., Serengil Y., Gokbulak F., Sengonul K., Ozhan S., Kılıc U, Uygur B., Ozcelik M., 2018. Results of a paired catchment analysis of forest thinning in Turkey in relation to forest management options. Science of the Total Environment 618: 785-792. https:// doi.org/10.1016/j.scitotenv.2017.08.190

Yücedag C., Gailing O., 2013. Morphological and genetic variation within and among four Quercus petraea and Q. robur natural populations. Turkish Journal of Botany 37: 619-629. Doi:10.3906/bot-1205-18

Zimmermann R., Schulze E-D., Wirth C., Schulze E.-E., McDonald K.C., Vygodskaya N.N., Ziegler W., 2000. Canopy transpiration in a chronosequence of Central Siberian pine forests. Global Change Biology 6: 25-37. https://doi.org/10.1046/j.1365-2486.2000.00289.x 